\title{
Influence of concurrent medications on outcomes of men with prostate cancer included in the TAX 327 study
}

\author{
Saroj Niraula, MD; ${ }^{*}$ Greg Pond, PhD, PStat; ${ }^{\dagger}$ Ronald de Wit, MD, PhD; $;^{\S}$ Mario Eisenberger, MD; \\ lan F. Tannock, MD, PhD; ${ }^{*}$ Anthony M. Joshua, BSc(Med) MBBS PhD FRACP*
}

*Division of Medical Oncology, Princess Margaret Hospital/University of Toronto, Toronto, ON; †Department of Oncology, McMaster University, Hamilton, ON; §Department of Medical Oncology, Rotterdam

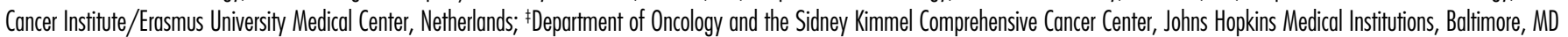

Cite as: Can Urol Assoc J 2013;7:E74-E81. http://dx.doi.org/10.5489/cuaj.267. Epub 2011 November 2.

\section{Abstract}

Objectives: The TAX 327 trial was pivotal in establishing docetaxel in castration refractory metastatic prostate cancer. Various commonly prescribed and over-the-counter co-administered medications are thought to exhibit anti-neoplastic properties and/or could potentially have pharmacokinectic interactions with docetaxel lessening the effectiveness of chemotherapy.

Methods: To examine the effect of on prostate cancer outcomes within this trial, we examined overall survival, prostate-specific antigen (PSA) response, percent PSA reduction, pain response and QOL responses for 14 families of medications including metformin, digoxin, verapamil, proton pump inhibitors, nitrates, statins, cox-2 inhibitors, warfarin, heparins, ascorbic acid, selenium, tocopherol, antidepressants and erythropoietin.

Results: Our findings did not reveal any medication that had a significant additive or synergistic effect with docetaxel. We did note, however, that patients on digoxin or verapamil had poorer overall survival, possibly due to a trend of fewer cycles of administered chemotherapy being administered to the verapamil group, consistent with a pharmacokinectic interaction.

Conclusions: These data are only hypothesis-generating given the statistical limitations, but may form a basis for similar future analysis in other malignancies. The data suggest the need to be aware of pharmacokinectic interactions with medications that may interact with docetaxel.

\section{Introduction}

Patients with advanced cancer receiving chemotherapy generally require multiple medications for concurrent illnesses, treatment-related toxicities or for pain control. There is growing interest in potential anti-tumour properties of some prescription drugs; conversely, there is that these same drugs may increase the likelihood of adverse drug interactions. The most recent analysis of concomitant medications taken by cancer patients suggests that patients take an average of 4.8 prescription drugs, 1.6 non-prescription drugs and 1.6 other remedies within the 3 days before chemotherapy. ${ }^{1}$

The large database $(n=1006)$ of the TAX 327 study provided us with an opportunity to evaluate concomitant medications taken by the patients at baseline and their influence on treatment outcomes. TAX 327 was a landmark study showing survival advantage in men treated with docetaxel 3 times weekly compared to docetaxel once a week and mitoxantrone as initial chemotherapy for castrate-resistant, metastatic prostate cancer. ${ }^{2}$

\section{Methods}

We identified patients taking selected concomitant medications while receiving study treatment as part of the TAX 327 study. We examined 14 types of medications (metformin, digoxin, verapamil, proton pump inhibitors, nitrates, statins, cox-2 inhibitors, warfarin, heparins, ascorbic acid, selenium, tocopherol, antidepressants and erythropoietin) taken concurrently with chemotherapy and prednisone and analyzed them for their association with overall survival (primary endpoint), PSA-response rate, percent PSA-reduction from baseline to on-treatment nadir, pain-response and quality of life (QOL)-response. Each of these measures was defined as per the TAX 327 study, ${ }^{2}$ aside from PSA shrinkage (Appendix 1). Each of these selected medications was taken by at least 20 men in the study. Medications were selected because of their putative anti-neoplastic effects (Table 1). We detailed selected data suggesting that specific concurrent medications have an effect on outcome measures in Table 2 and Table 3 (greater details in Appendix 2 to 9). For all outcomes, both unadjusted tests and adjusted tests were examined. Unless otherwise specified, the adjusted test results are discussed in the text with both sets of results presented in the online supplementary tables. Overall survival was estimated using the Kaplan-Meier method, and is based on the updated survival analysis. ${ }^{3}$ Cox proportional hazards models were used to estimate the hazards ratio (HR) and $p$-value comparing 


\section{Table 1. Rationale for selection of some of the concomitant medications in the TAX 327 database, with putative mechanisms of action and pharmacokinectic interactions with docetaxel}

\begin{tabular}{|c|c|c|}
\hline Agent & $\begin{array}{l}\text { Purported mechanism of anti-cancer action } \\
\text { and references }\end{array}$ & Overview of evidence \\
\hline Metformin & AMPK activation, ${ }^{9}$ cyclin D1 inhibition. ${ }^{10}$ & $\begin{array}{l}\text { Population-based study has shown decreased prostate } \\
\text { cancer risk with use of metformin. }{ }^{11}\end{array}$ \\
\hline Digoxin & Inhibition of HIF1. ${ }^{4,5}$ & $\begin{array}{l}\text { Digitalis inhibits proliferation of prostate cancer cell } \\
\text { lines. } .^{12}\end{array}$ \\
\hline Nitrates & $\begin{array}{l}\text { Attenuates hypoxia induced tumour growth/drug- } \\
\text { resistance. }{ }^{13}\end{array}$ & $\begin{array}{l}\text { Prolonged PSA doubling time with use of glyceryl } \\
\text { trinitrate in recurrent prostate cancer patients in a phase } \\
\text { Il study. }{ }^{14}\end{array}$ \\
\hline PPI & $\begin{array}{l}\text { Tumour alkalization, inhibition of autophagy and } \\
\text { P-glycoprotein antagonist. }{ }^{15}\end{array}$ & Limited evidence. \\
\hline Verapamil & $\begin{array}{l}\text { Reversal of multidrug resistance, inhibition of voltage- } \\
\text { gated } \mathrm{K}+\text { channel. }{ }^{16,17} \text { However, CYP3A4 inhibitor, } \\
\text { potentially increasing docetaxel concentration. }{ }^{18}\end{array}$ & Inhibition of proliferation in LNCaP. ${ }^{6}$ \\
\hline Statins & $\begin{array}{l}\text { Inhibitory effects on angiogenesis, cell proliferation and } \\
\text { invasion. }{ }^{19} \text { However, may possibly compete for CYP3A4 } \\
\text { metabolism (atorvastatin, lovastatin, simvastatin). }\end{array}$ & $\begin{array}{l}\text { Reduced risk of prostate cancer and of biochemical } \\
\text { recurrence after prostatectomy. }{ }^{20,21}\end{array}$ \\
\hline Cox-2 inhibitors & $\begin{array}{l}\text { Converts arachnoidic acid to prostaglandins which } \\
\text { inhibit apoptosis, stimulate cell proliferation and } \\
\text { facilitate angiogenesis. }{ }^{22}\end{array}$ & $\begin{array}{l}\text { Decreased tumour cell proliferation, microvessel } \\
\text { density, angiogenesis and HIF-1 and increased apoptosis } \\
\text { associated with celecoxib. } .^{23}\end{array}$ \\
\hline Warfarin & $\begin{array}{l}\text { Inhibition of fibrin formation, reduction of urokinase } \\
\text { receptor expression, and inhibition of thrombin } \\
\text { generation, release of metalloproteinase- } 2 \text { from } \\
\text { subendothelial matrix. }{ }^{24} \text { Also may compete for CYP3A4 }\end{array}$ & $\begin{array}{l}\text { Warfarin showed anti-metastatic activity in pre-clinical } \\
\text { prostate cancer models }{ }^{25} \text { and showed antitumour activity } \\
\text { in prostate cancer in a population based study., } .^{826}\end{array}$ \\
\hline
\end{tabular}

Ascorbic acid

Lycopene

Tocopherol

Selenium

Heparins

Antidepressants

Erythropoietin subendothelial matrix. ${ }^{24}$ Also may compete for CYP3A4 with docetaxel for metabolism.

Ascorbic acid: direct cytotoxicity by hydrogenperoxide ${ }^{27}$ and antioxidant properties.

Lycopene thought to act through Ras and mevalonate..$^{28}$

Induces apoptosis via caspase dependent and independent mechanisms in vitro and in vitro. ${ }^{29}$ Possibly by affecting interrupting sphingolipid synthesis. ${ }^{31}$ May also affect NF-Kb activation. ${ }^{32}$

May contribute to elevation of the endogenous inhibitor of angiogenesis, platelet factor- $4,{ }^{41}$ inhibiting nuclear translocation of the NF-Kb and the subsequent production of the immunosuppressive cytokine TGFbeta, VEGF and IL-6; ${ }^{42}$ increases the activity of PTEN. ${ }^{43}$

Possible role in decreasing metastases formation via decreasing adhesion. ${ }^{35}$

Selective serotonin reuptake inhibitors and monoamine oxidase inhibitors may decrease prostate cancer growth. ${ }^{38}$

May promote growth of prostate cancer cells. ${ }^{39}$
Limited evidence.

A prospective study of tomato products (lycopene) was associated with decreased prostate cancer risk. ${ }^{30}$

Effects found in prostate cancer cell lines and xenografts. ${ }^{34}$

Evidence from mouse and rat prostate models..$^{33,44}$ Early human evidence of a benefit in preventing carcinogenesis not validated.

In vitro models and rat prostate models. ${ }^{36}$

In vitro proliferation experiments. ${ }^{37}$

Experiments in prostate cancer cell lines and indirect evidence from human tumours. ${ }^{40}$

PSA: prostate-specific antigen; PPI: proton pump inhibitors; LNCaP: Human prostate adenocarcinoma cell line; NF-Kb: nuclear factor kappaB; TGF-beta: Transforming Growth Factor-beta; VEGF: Vascular endothelial growth factor; IL-6: interleukin-6; PTEN: phosphatase and tensin homologue.

patients who received each concomitant medication to those who did not receive it. The proportion of patients having a PSA-response, differences in PSA reduction, pain-response and QOL-response were calculated for patients receiving (or not) each concomitant medication. The unadjusted $p$-value was calculated using Fisher's exact test, and adjusted $p$-values using the Cochran-Mantel-Haenszel test, adjusted for treatment group. The homogeneity of odds ratios was tested using the Breslow-Day test and used to determine whether the estimated odds ratio is different between the three treatment groups. Duration of intravenous chemotherapy was compared using Wilcoxon rank sum tests (unadjusted analysis) and linear regression (adjusted analysis). The median and inter-quartile range was calculated for patients receiving (or not) each concomitant medication, and these were compared using the Wilcoxon rank sum test. Statistical significance was set at $p=0.05$ and no $p$-value adjustment was performed for multiple hypothesis testing. All tests were two-sided. 


\begin{tabular}{|c|c|c|c|c|c|c|}
\hline \multirow[t]{2}{*}{ Outcome } & \multirow[t]{2}{*}{$\begin{array}{l}\text { Concomitant } \\
\text { medication }\end{array}$} & \multirow{2}{*}{$\begin{array}{c}\mathrm{N} \\
\text { (D3W/D1W/M) }\end{array}$} & \multirow[t]{2}{*}{ Total patients } & \multicolumn{3}{|c|}{ Groups } \\
\hline & & & & D3W & D1W & $\mathbf{M}$ \\
\hline \multirow[t]{2}{*}{ os } & Digoxin & $10: 14: 11$ & 35 & 0.023 & 0.3 & 0.7 \\
\hline & Verapamil & $16: 11: 16$ & 43 & 0.062 & 0.14 & 0.29 \\
\hline PSA decline & Warfarin & $22: 23: 24$ & 69 & 0.047 & 0.35 & 0.52 \\
\hline \multirow[t]{3}{*}{ Pain response } & Antidepressants & $27: 21: 17$ & 65 & 0.61 & 0.018 & 0.46 \\
\hline & Epoetin & $16: 26: 19$ & 61 & 0.009 & 0.79 & 0.68 \\
\hline & Digoxin & $10: 14: 11$ & 35 & 0.096 & 0.38 & 0.58 \\
\hline \multirow[t]{2}{*}{ QOL response } & Cox-2 inhibitors & $37: 34: 29$ & 80 & 0.27 & 0.48 & 0.06 \\
\hline & Statins & $28: 21: 33$ & 82 & 0.021 & 0.26 & 0.36 \\
\hline
\end{tabular}

OS: overall survival; PSA: prostate-specific antigen; QOL: quality of life; D3W: docetaxel 3 weekly; D1W: docetaxel weekly; M: mitoxantrone; N: number of patients in each group.

\section{Results}

Patients taking verapamil and digoxin had worse overall survival than patients who did not (adjusted analysis using data from all 3 treatment cohorts: digoxin HR 1.43 (1.012.03), $p=0.046$; verapamil HR 1.51 (1.10-2.08), $p=0.011)$. These differences in survival were consistent within each of the 3 treatments, but were most pronounced in the docetaxel 3-weekly treatment group. Interestingly, the duration of intravenous chemotherapy comparing the median duration for those on verapamil with the median duration of those not on verapamil approached statistical significance (unadjusted $p=0.080$ and adjusted $p=0.070$ ). Those on verapamil appeared to have reduced weeks on chemotherapy compared with those not on verapamil.

No concomitant medication had a statistically significant effect on PSA-response rate, although men taking warfarin had greater PSA reduction than those not taking it (PSA reduction $49.0 \%$ [-5.5, 85.3] vs. $69.2 \%$ [20.3, 90.8], unadjusted $p=0.047$, adjusted $p=0.035$ ). Men taking antidepressants had lower rates of pain-response than those not taking antidepressants (unadjusted $p=0.045$; CochranMantel-Haenszel $[\mathrm{CMH}]$ test $p=0.028$; homogeneity of odds ratios $p=0.19$ ). The QOL response rates were significantly higher (unadjusted $p=0.032 ; \mathrm{CMH} p=0.031$; homogeneity of odds ratios $p=0.49$ ) among patients who received cox-2 inhibitors than those who did not.

\section{Discussion}

Our analysis revealed a number of possible associations between concomitant medications and outcome measures in the TAX-327 trial. The use of digoxin was associated with poorer overall survival within all three treatment groups. Preclinical studies have shown digoxin to be a potential anticancer agent, ${ }^{6,7}$ but its effects here are likely due to the influence of comorbidity from the cardiac condition for which it was prescribed, an effect that would only be partially accounted for by the stratification for the Karnofsky performance status. Patients who took verapamil also had poorer overall survival, although other efficacy outcomes were not substantially different between those who did and did not take verapamil. This result is contrary to previous suggestions that verapamil can inhibit the proliferation of many tumour types, including prostate cancer, ${ }^{6}$ and, in higher does, can block the multi-drug resistance drug efflux pump. Patients receiving digoxin or verapamil probably represented a group of people who were more likely to have death related to cardiovascular disease; although, it is possible that competition for CYP3A4 and the inhibitory ability of verapamil on CYP3A4 also lead to more toxicity, abrogating the length of chemotherapy, a hypothesis supported by the trend to a decreased treatment duration in patients on verapamil. Unfortunately, it is not possible to extract causes of mortality from the trial records to clarify this issue.

Our analysis revealed that the degree of PSA reduction in men taking warfarin was higher than in those not taking this medication. Data are sparse on the effects of warfarin in prostate cancer treatment; a Canadian case-control study showed that 4 years of warfarin use was associated with an adjusted incidence rate ratio of $0.80(95 \% \mathrm{Cl} 0.65-0.99)$ for prostate cancer compared with that in people who never used warfarin; little research has been carried out subsequently. ${ }^{10}$

Patients concurrently taking antidepressants had poorer pain-response rates, and trends to poorer survival and PSAresponse rates $(p<0.10)$. The poorer pain response may be due to anxiety that was associated with conditions for which these medications were prescribed.

Our analysis of proton pump inhibitors and metformin, drugs with pre-clinical evidence to suggest potential antineoplastic activity (Table 1), also did not reveal any association with outcome measures, although we noted trends for QOL response (unadjusted $p=0.074 ; \mathrm{CMH} p=0.074$; homogeneity of odds ratios 0.31 ) for metformin.

Despite pre-clinical, clinical and epidemiological observations that some of these medications are likely to exhibit anticancer properties, we were unable to detect sufficient activity to warrant testing with docetaxel in future studies. There are a number of potential reasons for this. It is impor- 


\begin{tabular}{|c|c|c|c|c|c|c|}
\hline Drug & n (\%) & $\begin{array}{c}\text { Treatment } \\
\text { D3W:D1W:M }\end{array}$ & $\begin{array}{l}\text { Median }(95 \% \\
\text { Cl) survival, no } \\
\text { concomitant } \\
\text { medication }\end{array}$ & $\begin{array}{l}\text { Median }(95 \% \\
\text { Cl) survival, } \\
\text { concomitant } \\
\text { medication }\end{array}$ & $\begin{array}{c}\text { Unadjusted } \\
\text { HR (95\% Cl) } \\
\text { p-value }\end{array}$ & $\begin{array}{c}\text { Adjusted HR }(95 \% \\
\text { Cl) } \\
p \text {-value }\end{array}$ \\
\hline Metformin & $38(3.8)$ & 17:10:11 & $17.3(16.3-18.4)$ & $18.2(13.1-25.5)$ & $\begin{array}{c}1.00(0.70-1.42) \\
1.00\end{array}$ & $\begin{array}{c}0.99(0.69-1.41) \\
0.96\end{array}$ \\
\hline PPI & $223(22.2)$ & $74: 92: 57$ & $17.2(16.3-18.6)$ & $17.8(15.3-19.7)$ & $\begin{array}{c}0.96(0.82-1.12) \\
0.60\end{array}$ & $\begin{array}{c}0.92(0.79-1.08) \\
0.31\end{array}$ \\
\hline Glyceryl & $51(5.1)$ & 21:15:15 & $17.5(16.6-18.7)$ & $13.5(10.3-17.2)$ & $\begin{array}{c}1.19(0.88-1.60) \\
0.27\end{array}$ & $\begin{array}{c}1.16(0.86-1.57) \\
0.35\end{array}$ \\
\hline Digoxin & $35(3.5)$ & $10: 14: 11$ & $17.4(16.5-18.6)$ & $12.0(7.3-17.5)$ & $\begin{array}{c}1.54(1.09-2.17) \\
0.014\end{array}$ & $\begin{array}{c}1.43(1.01-2.03) \\
0.046\end{array}$ \\
\hline Verapamil & $43(4.3)$ & 16:11:16 & $17.4(16.5-18.6)$ & $12.9(8.1-17.5)$ & $\begin{array}{c}1.51(1.10-2.07) \\
0.011\end{array}$ & $\begin{array}{c}1.51(1.10-2.08) \\
0.011\end{array}$ \\
\hline 'Statin' & $82(8.2)$ & $28: 21: 33$ & $17.3(16.3-18.4)$ & $17.3(14.8-22.6)$ & $\begin{array}{c}0.94(0.74-1.19) \\
0.60\end{array}$ & $\begin{array}{c}0.97(0.76-1.23) \\
0.80\end{array}$ \\
\hline ‘Coxib’ & $100(9.9)$ & $37: 34: 29$ & $17.3(16.4-18.5)$ & $16.5(14.1-19.7)$ & $\begin{array}{c}1.05(0.84-1.30) \\
0.69\end{array}$ & $\begin{array}{c}1.02(0.82-1.28) \\
0.85\end{array}$ \\
\hline Warfarin & $69(6.9)$ & $22: 23: 24$ & $17.3(16.3-18.5)$ & $17.3(15.1-20.5)$ & $\begin{array}{c}1.04(0.81-1.34) \\
0.76\end{array}$ & $\begin{array}{c}1.01(0.79-1.31) \\
0.91\end{array}$ \\
\hline ‘Parin' & $57(5.7)$ & 21:17:19 & $17.5(16.6-18.6)$ & $15.1(11.4-17.5)$ & $\begin{array}{c}0.13(0.85-1.50) \\
0.41\end{array}$ & $\begin{array}{c}1.14(0.86-1.52) \\
0.36\end{array}$ \\
\hline Ascorbic acid & $42(4.2)$ & 17:13:12 & $17.2(16.3-18.4)$ & $18.1(15.1-22.8)$ & $\begin{array}{c}0.96(0.69-1.34) \\
0.81\end{array}$ & $\begin{array}{c}0.96(0.69-1.34) \\
0.81\end{array}$ \\
\hline Selenium & $24(2.4)$ & $9: 6: 9$ & $17.3(16.4-18.4)$ & $19.7(11.2-30.7)$ & $\begin{array}{c}0.87(0.57-1.32) \\
0.51\end{array}$ & $\begin{array}{c}0.91(0.60-1.37) \\
0.64\end{array}$ \\
\hline Tocopherol & $56(5.6)$ & 19:18:19 & $17.2(16.3-18.4)$ & $17.6(14.6-28.4)$ & $\begin{array}{c}0.85(0.63-1.13) \\
0.26\end{array}$ & $\begin{array}{c}.87(0.65-1.16) \\
0.33\end{array}$ \\
\hline Antidepressants & $65(6.5)$ & $27: 21: 17$ & $17.4(16.6-18.7)$ & $15.1(11.3-17.7)$ & $\begin{array}{c}1.34(1.03-1.74) \\
0.028\end{array}$ & $\begin{array}{c}1.27(0.97-1.64) \\
0.079\end{array}$ \\
\hline Epoetin & $61(6.1)$ & 16:26:19 & $17.5(16.6-18.7)$ & $14.3(12.3-17.3)$ & $\begin{array}{c}1.42(1.09-1.85) \\
0.010\end{array}$ & $\begin{array}{c}1.23(0.94-1.61) \\
0.13\end{array}$ \\
\hline Aspirin & $170(16.9)$ & $49: 61: 60$ & $17.1(16.2-18.6)$ & $17.6(15.5-19.2)$ & $\begin{array}{c}1.02(0.85-1.21) \\
0.87\end{array}$ & $\begin{array}{c}.01(0.85-1.20) \\
0.91\end{array}$ \\
\hline
\end{tabular}

Cl: confidence interval; HR: hazard ratio; D3W: docetaxel 3 weekly; D1W: docetaxel weekly; M: mitoxantrone; PPI: proton pump inhibitors; $†$ adjusted for treatment group, and stratified by baseline pain and baseline Karnofsky performance status.

tant to note that most preclinical (and clinical) data supporting the potential anti-cancer properties of most of the agents included in these studies were based on reports excluding combinations with chemotherapy; the current analysis, however, focused on the possibility of combined effects. Additionally, our analyses was restricted by the limited data on the pharmacokinectic interactions with docetaxel and the medications listed other than theorectical interactions with verapamil, diltaizem (inhibitors of CYP3A4), numerous SSRIs (selective serotonin reuptake inhibitors) (including citalopram, sertraline, which may compete for CYP 3A4) and some statins (atorvastatin, lovastatin and simvastation, which may also compete for CYP3A4).

Finally, there are a number of limitations of secondary analyses, such as multiple hypothesis testing, patient comorbidities, and small numbers of patients taking individual drugs to the extent that we were unable to confidently exclude the effect of any concomitantly taken medication given the confidence intervals surrounding them. Future efforts may concentrate on recent large clinical trials with patients at earlier stages of disease (and with fewer comorbidities), such as those with asymptomatic metastatic castrate refractory disease. These efforts will allow us to examine these issues in combination with either pharmacogenetic or physiological data to refine an hypothesis (e.g., does the presence of the insulin resistance syndrome portend a shorter response to hormonal therapies that can be reversed with metformin?).

\section{Conclusion}

Our data are hypothesis-generating and contain a number of important clinical research negative findings, such as the lack of benefit of metformin and the potentially concerning data about verapamil. This data is the only one of its kind available for prostate cancer. Aside from some case-control analyses of breast cancer populations examining the use of SSRIs and tamoxifen, ${ }^{45-47}$ there are no similar analyses in the literature for any malignancy. Therefore, our study provides 
a basis for evaluating other trials for similar effects, which may reveal unanticipated findings that would warrant further research.

Competing interests: Dr. de Wit, Dr. Eisenberger and Dr. Tannock have received research funding from sanofi-aventis.

This paper has been peer-reviewed.

\section{References}

1. Hanigan MH, del Cruz BL, Shord SS, et al. Optimizing Chemotherapy: Concomitant Medication Lists. Clin Pharmacol Ther 2011;89:114-9.

2. Tannock IF, de Wit R, Berry WR, et al. Docetaxel plus prednisone or mitoxantrone plus prednisone for advanced prostate cancer. N Engl J Med 2004;351:1502-12.

3. Berthold DR, Pond GR, Soban F, et al. Docetaxel plus prednisone or mitoxantrone plus prednisone for advanced prostate cancer: updated survival in the TAX 327 study. J Clin Oncol 2008;26:242-5.

4. Lopez-Lazaro M. Digoxin. HIF-1, and cancer. Proc Natl Acad Sci U S A 2009;106:E26; author reply E27.

5. Zhang H, Qian DZ, Tan YS, et al. Digoxin and other cardiac glycosides inhibit HIF-lalpha synthesis and block tumor growth. Proc Natt Acad Sci U S A 2008;105:19579-86.

6. Rybalchenko V, Prevarskaya N, Van Coppenolle F, et al. Verapamil inhibits proliferation of LNCaP human prostate cancer cells influencing $\mathrm{K}+$ channel gating. Mol Pharmacol 2001;59:1376-87.

7. Theyer G, Schirmbock M, Thalhammer T, et al. Role of the MDR-1-encoded multiple drug resistance phenotype in prostate cancer cell lines. J Urol 1993;150:1544-7.

8. Tagalakis $\mathrm{V}$, Tamim H, Blostein $\mathrm{M}$, et al. Use of warfarin and risk of urogenital cancer: a population-based, nested case-control study. Lancet Oncol 2007;8:395-402.

9. Zakikhani M, Dowling RJ, Sonenberg N, et al. The effects of adiponectin and metformin on prostate and colon neoplasia involve activation of AMP-activated protein kinase. Cancer Prev Res (Phila) 2008;1:36975.

10. Ben Sahra I, Laurent $K$, Loubat A, et al. The antidiabetic drug metformin exerts an antitumoral effect in vitro and in vivo through a decrease of cyclin D1 level. Oncogene 2008:27:3576-86.

11. Wright JL, Stanford JL. Mefformin use and prostate cancer in Caucasian men: results from a populationbased case-control study. Cancer Causes Control 2009;20:1617-22.

12. Yeh JY, Huang WJ, Kan SF, et al. Inhibitory effects of digitalis on the proliferation of androgen dependent and independent prostate cancer cells. J Urol 2001;166:1937-42.

13. Frederiksen $\mathrm{U}$, Siemens DR, Heaton JP, et al. Hypoxia induced resistance to doxorubicin in prostate cancer cells is inhibited by low concentrations of glyceryl trinitrate. J Urol 2003;170:1003-7.

14. Siemens DR, Heaton JP, Adams MA, et al: Phase II study of nitric oxide donor for men with increasing prostate-specific antigen level after surgery or radiotherapy for prostate cancer. Urology 2009;74:878-83.

15. Tannock IF, Rotin D: Acid pH in tumors and its potential for therapeutic exploitation. Cancer Res 1989:49:4373-84

16. Gottesman MM, Pastan I. Clinical trials of agents that reverse multidrug-resistance. J Clin Oncol 1989;7:409-11.

17. Choi SU, Lee CO, Kim KH, et al. Reversal of multidrug resistance by novel verapamil analogs in cancer cells. Anticancer Drugs 1998;9:157-65.

18. Royer I, Monsarrat B, Sonnier M, et al: Metabolism of docetaxel by human cytochromes P450: interactions with paclitaxel and other antineoplastic drugs. Cancer Res 1996:56:58-65.

19. Weis $M$, Heeschen C, Glassford A, et al. Statins have biphasic effects on angiogenesis. Circulation 2002; 105:739-45.

20. Hamilton RJ, Banez LL, Aronson WJ, et al. Statin medication use and the risk of biochemical recurrence after radical prostatectomy: results from the Shared Equal Access Regional Cancer Hospital (SEARCH) Database. Cancer 2010;116:3389-98.

21. Shannon J, Tewoderos $S$, Garzotto $M$, et al. Statins and prostate cancer risk: a case-control study. Am J Epidemiol 2005;162:318-25.
22. Dannenberg AJ, Subbaramaiah K. Targeting cyclooxygenase-2 in human neoplasia: rationale and promise. Cancer Cell 2003;4:431-6.

23. Sooriakumaran P, Coley HM, Fox SB, et al. A randomized controlled trial investigating the effects of celecoxib in patients with localized prostate cancer. Anticancer Res 2009;29:1483-8.

24. Falanga A, Piccioli A. Effect of anticoagulant drugs in cancer. Curr Opin Pulm Med 2005;11:403-7.

25. Maucher $A$, Kager $M$, von Angerer E. Evaluation of the antitumour activity of coumarin in prostate cancer models. J Cancer Res Clin Oncol 1993;119:150-4.

26. Zacharski LR, Henderson WG, Rickles FR, et al. Effect of warfarin anticoagulation on survival in carcinoma of the lung, colon, head and neck, and prostate. Final report of VA Cooperative Study \#75. Cancer 1984;53:2046-52

27. Frei B, Lawson S. Vitamin C and cancer revisited. Proc Natl Acad Sci U S A 2008;105:11037-8.

28. Palozza $P$, Colangelo $M$, Simone $R$, et al: Lycopene induces cell growth inhibition by altering mevalonate pathway and Ras signaling in cancer cell lines. Carcinogenesis 2010;31:1813-21.

29. Jiang Q, Wong J, Ames BN. Gamma-tocopherol induces apoptosis in androgen-responsive LNCaP prostate cancer cells via caspase-dependent and independent mechanisms. Ann N Y Acad Sci 2004;1031:399-400.

30. Giovannucci E, Rimm EB, Liu Y, et al: A prospective study of tomato products, lycopene, and prostate cancer risk. J Natl Cancer Inst 2002:94:391-8.

31. Jiang $Q$, Wong J, Fyrst $H$, et al. gamma-Tocopherol or combinations of vitamin $E$ forms induce cell death in human prostate cancer cells by interrupting sphingolipid synthesis. Proc Natl Acad Sci U S A 2004:101:17825-30

32. Crispen PL, Uzzo RG, Golovine K, et al. Vitamin E succinate inhibits NF-kappaB and prevents the development of a metastatic phenotype in prostate cancer cells: implications for chemoprevention. Prostate 2007;67:582-90

33. Lindshield BL, Ford NA, Canene-Adams K, et al. Selenium, but not lycopene or vitamin E, decreases growth of transplantable dunning R3327-H rat prostate tumors. PLoS One 2010;5:e10423.

34. Malafa MP, Fokum FD, Andoh J, et al. Vitamin E succinate suppresses prostate tumor growth by inducing apoptosis. Int J Cancer 2006;118:2441-7.

35. Lersch C, Gericke D, Classen M. Efficacy of low-molecular-weight heparin and unfractionated heparin to prevent adhesion of human prostate and bladder carcinoma and melanoma cells to bovine endothelial monolayers. An in vitro study and review of the literature. Urol Int 1996;56:230-3.

36. Drago JR, Weed $\mathrm{P}$, Fralisch $\mathrm{A}$. The evaluation of heparin in control of metastasis of $\mathrm{Nb}$ rat androgeninsensitive prostate carcinoma. Anticancer Res 1984;4:171-2.

37. Abdul M, Logothetis CJ, Hoosein NM. Growth-inhibitory effects of serotonin uptake inhibitors on human prostate carcinoma cell lines. J Urol 1995;154:247-50.

38. Peehl DM, Coram M, Khine H, et al. The significance of monoamine oxidase-A expression in high grade prostate cancer. J Urol 2008;180:2206-11.

39. Feldman L, Wang Y, Rhim JS, et al: Erythropoietin stimulates growth and STAT5 phosphorylation in human prostate epithelial and prostate cancer cells. Prostate 2006;66:135-45.

40. Jeong JY, Hoxhai G, Socha AL, et al. An erythropoietin autocrine/paracrine axis modulates the growth and survival of human prostate cancer cells. Mol Cancer Res 2009;7:1150-7.

41. Cervi D, Pak B, Venier NA, et al. Micronutrients attenuate progression of prostate cancer by elevating the endogenous inhibitor of angiogenesis, platelet factor-4. BMC Cancer 2010;10:258.

42. Pei Z, Li H, Guo Y, et al. Sodium selenite inhibits the expression of VEGF, TGFbeta (I) and IL-6 induced by LPS in human PC3 cells via TLR4-NF-(K)B signaling blockage. Int Immunopharmacol 2010;10:50-6.

43. Berggren $M$, Sittadiody $S$, Song $Z$, et al. Sodium selenite increases the activity of the tumor suppressor protein, PTEN, in DU-145 prostate cancer cells. Nutr Cancer 2009;61:322-31.

44. Wang L, Bonorden MJ, Li GX, et al. Methyl-selenium compounds inhibit prostate carcinogenesis in the transgenic adenocarcinoma of mouse prostate model with survival benefit. Cancer Prev Res (Phila) 2009;2:484-95.

45. Lash TL, Cronin-Fenton D, Ahern TP, et al. Breast cancer recurrence risk related to concurrent use of SSRI antidepressants and tamoxifen. Acta Oncol 2010;49:305-12.

46. Kelly CM, Juurlink DN, Gomes T, et al. Selective serotonin reuptake inhibitors and breast cancer mortality in women receiving tamoxifen: a population based cohort study. BMJ 2010;340:c693.

47. Lash TL, Pedersen L, Cronin-Fenton D, et al. Tamoxifen's protection against breast cancer recurrence is not reduced by concurrent use of the SSRI citalopram. Br J Cancer 2008:99:616-21

Correspondence: Dr. Anthony Joshua, Division of Medical Oncology, Princess Margaret Hospital, 610 University Ave., Toronto, 0N; fax: 416-946-6546; anthony.joshu@@uhn.on.co 


\begin{tabular}{|c|c|c|c|c|}
\hline \multicolumn{5}{|c|}{ Appendix 1. PSA-decline, a measure of the maximum fall of PSA from the starting value to its nadir } \\
\hline Drug & $\begin{array}{c}\text { Median (IQR) \% PSA- } \\
\text { shrinkage, no concomitant } \\
\text { medications }\end{array}$ & $\begin{array}{c}\text { Median (IQR) \% PSA- } \\
\text { shrinkage; concomitant } \\
\text { medications }\end{array}$ & Wilcoxon RS $p$-value & Adjusted $p$-value ${ }^{\dagger}$ \\
\hline Metformin & $50.2(-3.3,85.9)$ & $35.1(-27.4,83.3)$ & 0.14 & $0.25 / 0.25$ \\
\hline PPI & $49.3(-5.9,85.9)$ & $55.3(3.8,85.2)$ & 0.52 & $0.76 / 0.67$ \\
\hline Glyceryl & $49.6(-5.1,85.5)$ & $50.4(14.6,86.4)$ & 0.84 & $0.70 / 0.68$ \\
\hline Digoxin & $49.5(-4.3,85.5)$ & $55.1(14.1,86.5)$ & 0.96 & $0.97 / 0.90$ \\
\hline Verapamil & $50.2(-4.7,85.5)$ & $46.1(9.4,90.6)$ & 0.57 & $0.29 / 0.25$ \\
\hline 'Statin' & $49.6(-5.4,85.9)$ & $49.7(12.1,76.1)$ & 0.77 & $0.64 / 0.70$ \\
\hline 'Coxib' & $49.2(-6.7,85.2)$ & $53.5(18.2,88.3)$ & 0.11 & $0.058 / 0.057$ \\
\hline Warfarin & $49.0(-5.5,85.3)$ & $69.2(20.3,90.8)$ & 0.047 & $0.035 / 0.034$ \\
\hline ‘Parin’ & $49.3(-5.6,85.3)$ & $72.6(28.3,88.3)$ & 0.10 & $0.14 / 0.16$ \\
\hline Ascorbic Acid & $50.0(-4.7,85.9)$ & $48.2(0,78.9)$ & 0.58 & $0.86 / 0.85$ \\
\hline Selenium & $50.0(-4.3,85.9)$ & $24.8(-3.0,82.0)$ & 0.61 & $0.91 / 0.88$ \\
\hline Tocopherol & $49.6(-4.8,85.6)$ & $54.4(0,82.0)$ & 0.85 & $0.96 / 0.93$ \\
\hline Antidepressants & $50.4(-4.3,85.6)$ & $45.3(-3.0,85.9)$ & 0.70 & $0.73 / 0.74$ \\
\hline Epoetin & $49.6(-5.4,85.8)$ & $55.1(18.3,80.9)$ & 0.41 & $0.19 / 0.15$ \\
\hline Aspirin & $49.9(-5.4,85.6)$ & $49.6(7.5,85.5)$ & 0.82 & $0.38 / 0.42$ \\
\hline
\end{tabular}

Appendix 2. Overall survival by treatment for concomitant medications significantly different overall

\begin{tabular}{|c|c|c|c|c|c|c|c|c|c|}
\hline & \multicolumn{3}{|c|}{ D3W } & \multicolumn{3}{|c|}{ D1W } & \multicolumn{3}{|c|}{ M } \\
\hline & Median $(95 \% \mathrm{Cl})$ & $\begin{array}{c}\text { HR } \\
(95 \% \mathrm{Cl})\end{array}$ & $p$-value & Median (95\% Cl) & $\begin{array}{c}\text { HR } \\
(95 \% \mathrm{Cl})\end{array}$ & $p$-value & Median (95\% Cl) & $\begin{array}{c}\text { HR } \\
(95 \% \mathrm{Cl})\end{array}$ & $p$-value \\
\hline $\begin{array}{l}\text { Digoxin } \\
\text { No Digoxin }\end{array}$ & $\begin{array}{c}7.6(2.6-17.1) \\
19.1(17.3-21.2)\end{array}$ & $\begin{array}{c}2.10 \\
1.11-3.96\end{array}$ & 0.023 & $\begin{array}{c}15.3(6.1-25.6) \\
17.4(15.9-18.8)\end{array}$ & $\begin{array}{c}1.35 \\
0.77-2.36\end{array}$ & 0.30 & $\begin{array}{c}14.9(9.6-19.2) \\
15.8(14.1-17.5)\end{array}$ & $\begin{array}{c}1.14 \\
0.59-2.22\end{array}$ & 0.70 \\
\hline $\begin{array}{l}\text { Verapamil } \\
\text { No Verapamil }\end{array}$ & $\begin{array}{c}11.7(6.1-19.8) \\
19.1(17.3-21.2)\end{array}$ & $\begin{array}{c}1.68 \\
0.97-2.89\end{array}$ & 0.062 & $\begin{array}{c}9.9(6.1-21.3) \\
17.6(16.1-19.0)\end{array}$ & $\begin{array}{c}1.59 \\
0.86-2.93\end{array}$ & 0.14 & $\begin{array}{c}15.8(8.0-20.0) \\
15.8(13.5-17.3)\end{array}$ & $\begin{array}{c}1.33 \\
0.79-2.26\end{array}$ & 0.29 \\
\hline
\end{tabular}

Cl: confidence interval; HR: hazard ratio; D3W: docetaxel 3 weekly; D1W: docetaxel weekly; M: mitoxantrone.

\begin{tabular}{|c|c|c|c|c|}
\hline \multicolumn{5}{|c|}{ Appendix 3. PSA-response } \\
\hline Drug & n (\%) PSA-response & Unadjusted $p$-value & CMH $p$-value & $\begin{array}{l}\text { Homogeneity of } \\
\text { odds ratios }\end{array}$ \\
\hline Metformin & $10 / 31(32 \%)$ & 0.35 & 0.24 & 0.071 \\
\hline PPI & $83 / 188$ (44\%) & 0.40 & 0.69 & 0.89 \\
\hline Glyceryl & $16 / 43(37 \%)$ & 0.64 & 0.54 & 0.94 \\
\hline Digoxin & $12 / 30(40 \%)$ & 1.00 & 0.79 & 0.78 \\
\hline Verapamil & $15 / 39(38 \%)$ & 0.74 & 0.81 & 0.24 \\
\hline 'Statin' & $21 / 63(33 \%)$ & 0.19 & 0.28 & 0.97 \\
\hline ‘Coxib’ & $40 / 89(45 \%)$ & 0.50 & 0.56 & 0.23 \\
\hline Warfarin & $30 / 59(51 \%)$ & 0.13 & 0.12 & 0.16 \\
\hline ‘Parin’ & $22 / 46(48 \%)$ & 0.44 & 0.38 & 0.49 \\
\hline Ascorbic Acid & $10 / 33(30 \%)$ & 0.21 & 0.18 & 0.83 \\
\hline Selenium & $6 / 21(29 \%)$ & 0.27 & 0.25 & 0.36 \\
\hline Tocopherol & $18 / 45(40 \%)$ & 0.88 & 0.93 & 0.43 \\
\hline Anti-Depressants & $19 / 59$ (32\%) & 0.17 & 0.095 & 0.82 \\
\hline Epoetin & $23 / 54(43 \%)$ & 0.89 & 0.88 & 0.21 \\
\hline Aspirin & $54 / 147$ (37\%) & 0.23 & 0.22 & 0.90 \\
\hline All patients & $362 / 873(41.5 \%)$ & - & - & - \\
\hline
\end{tabular}


Niraula et al.

Appendix 4. PSA-decline for warfarin/no warfarin patients, by treatment group

\begin{tabular}{lccccc} 
& \multicolumn{3}{c}{ No warfarin } & \multicolumn{3}{c}{ Warfarin } & \\
\cline { 2 - 5 } & $\mathbf{N}$ & Median (IOR) & N & Median (IOR) & p-value \\
\hline D3W & 258 & $56.0(-0.5,87.6)$ & 17 & $83.3(62.5,93.0)$ & 0.047 \\
D1W & 239 & $68.1(17.6,89.1)$ & 20 & $76.5(41.1,91.3)$ & 0.35 \\
M & 265 & $23.9(-17.2,73.5)$ & 21 & $29.2(-7.2,69.9)$ & 0.52 \\
\hline
\end{tabular}

PSA: prostate-specific antigen; D3W: docetaxel 3 weekly; D1W: docetaxel weekly; M: mitoxantrone; IQR: interquartile range.

\begin{tabular}{|c|c|c|c|c|}
\hline \multicolumn{5}{|c|}{ Appendix 5. Pain response } \\
\hline Drug & n (\%) pain-response & Unadjusted $p$-value & CMH p-value & Homogeneity of OR \\
\hline Metformin & $4 / 17(23.5)$ & 0.79 & 0.49 & 0.72 \\
\hline PPI & $35 / 119(29.4)$ & 1.00 & 0.88 & 0.96 \\
\hline Glyceryl & $9 / 25(36.0)$ & 0.50 & 0.50 & 0.37 \\
\hline Digoxin & $3 / 17(17.7)$ & 0.42 & 0.24 & 0.037 \\
\hline Verapamil & $7 / 23(30.4)$ & 1.00 & 0.93 & 0.71 \\
\hline 'Statin' & $7 / 35(20.0)$ & 0.25 & 0.20 & 0.42 \\
\hline ‘Coxib' & $19 / 49(38.8)$ & 0.13 & 0.14 & 0.063 \\
\hline Warfarin & $11 / 34(32.4)$ & 0.70 & 0.71 & 0.76 \\
\hline ‘Parin' & $7 / 32(21.9)$ & 0.42 & 0.32 & 0.46 \\
\hline Ascorbic acid & $3 / 20(15.0)$ & 0.21 & 0.15 & 0.41 \\
\hline Selenium & $3 / 11(27.3)$ & 1.00 & 0.90 & 0.44 \\
\hline Tocopherol & $7 / 26(26.9)$ & 1.00 & 0.72 & 0.042 \\
\hline Antidepressants & $6 / 40(15.0)$ & 0.045 & 0.028 & 0.19 \\
\hline Epoetin & $7 / 39(18.0)$ & 0.14 & 0.083 & 0.049 \\
\hline Aspirin & 22/71 (31.0) & 0.78 & 0.77 & 0.045 \\
\hline All patients & $135 / 464(29.1)$ & & & \\
\hline
\end{tabular}

PPI: proton pump inhibitors; CMH: Cochran-Mantel-Haenszel test; OR: odds ratio.

\begin{tabular}{|c|c|c|c|c|c|c|}
\hline \multicolumn{7}{|c|}{ Appendix 6. Pain-response rates by treatment group, based on non-homogenous OR or significance of OR } \\
\hline & \multicolumn{2}{|c|}{ D3W } & \multicolumn{2}{|c|}{ D1W } & \multicolumn{2}{|c|}{ M } \\
\hline & $\mathbf{N}(\%)$ & p-value & $\mathbf{N}(\%)$ & p-value & $\mathbf{N}(\%)$ & p-value \\
\hline $\begin{array}{l}\text { Digoxin } \\
\text { No Digoxin }\end{array}$ & $\begin{array}{c}0 / 7(0.0) \\
53 / 146(36.3)\end{array}$ & 0.096 & $\begin{array}{c}3 / 6(50.0) \\
45 / 148(30.4)\end{array}$ & 0.38 & $\begin{array}{c}0 / 4(0.0) \\
34 / 153(22.2)\end{array}$ & 0.58 \\
\hline $\begin{array}{l}\text { Antidepressants } \\
\text { No antidepressants }\end{array}$ & $\begin{array}{c}5 / 18(27.8) \\
48 / 135(35.6)\end{array}$ & 0.61 & $\begin{array}{c}0 / 11(0.0) \\
48 / 143(33.6)\end{array}$ & 0.018 & $\begin{array}{c}1 / 11(9.1) \\
33 / 146(22.6)\end{array}$ & 0.46 \\
\hline $\begin{array}{l}\text { Tocopherol } \\
\text { No tocopherol }\end{array}$ & $\begin{array}{c}6 / 11(54.6) \\
47 / 142(33.1)\end{array}$ & 0.19 & $\begin{array}{c}0 / 8(0.0) \\
48 / 146(32.9)\end{array}$ & 0.058 & $\begin{array}{c}1 / 7(14.3) \\
33 / 150(22.0)\end{array}$ & 1.00 \\
\hline $\begin{array}{l}\text { Epoetin } \\
\text { No epoetin }\end{array}$ & $\begin{array}{c}0 / 12(0.0) \\
53 / 141(37.6)\end{array}$ & 0.009 & $\begin{array}{c}6 / 18(33.3) \\
42 / 136(30.9)\end{array}$ & 0.79 & $\begin{array}{c}1 / 9(11.1) \\
33 / 148(22.3)\end{array}$ & 0.68 \\
\hline
\end{tabular}

OR: odds ratio; D3W: docetaxel 3 weekly; D1W: docetaxel weekly; M: mitoxantrone. 


\begin{tabular}{lcccc}
\hline Appendix 7. Quality of life response & & & \\
\hline Drug & $\mathbf{n}(\%)$ QOL-response & Unadjusted p-value & CMH p-value & Homogeneity of OR \\
\hline Metformin & $11 / 34(32.4)$ & 0.074 & 0.074 & 0.74 \\
PPI & $39 / 184(21.2)$ & 0.53 & 0.78 & 0.21 \\
Glyceryl & $10 / 46(21.7)$ & 0.70 & 0.39 & 0.15 \\
Digoxin & $4 / 29(13.8)$ & 0.63 & 0.90 & 0.10 \\
Verapamil & $7 / 39(18.0)$ & 1.00 & 0.087 & 0.71 \\
'Statin' & $8 / 70(11.4)$ & 0.083 & 0.031 & 0.024 \\
'Coxib' & $25 / 88(28.4)$ & 0.032 & 0.59 & 0.49 \\
Warfarin & $10 / 60(16.7)$ & 0.73 & 0.078 & 0.085 \\
'Parin' & $5 / 49(10.2)$ & 0.097 & 0.24 & 0.42 \\
Ascorbic acid & $5 / 40(12.5)$ & 0.31 & 0.58 & 0.33 \\
Selenium & $3 / 21(14.3)$ & 0.78 & 0.80 \\
Tocopherol & $9 / 50(18.0)$ & 1.00 & 0.48 & 0.25 \\
Antidepressants & $12 / 48(25.0)$ & 0.35 & 0.42 \\
Epoetin & $8 / 51(15.7)$ & 0.59 & 0.20 \\
Aspirin & $23 / 147(15.7)$ & 0.21 & & 0.50 \\
All patients & $159 / 815(19.5)$ & & & 0.32 \\
\hline PPI: proton pump inhibitors: CMH: Cochran-Mantel-Haenszel test: OR: odds ratio. & & & \\
\end{tabular}

PPI: proton pump inhibitors; CMH: Cochran-Mantel-Haenszel test; OR: odds ratio.

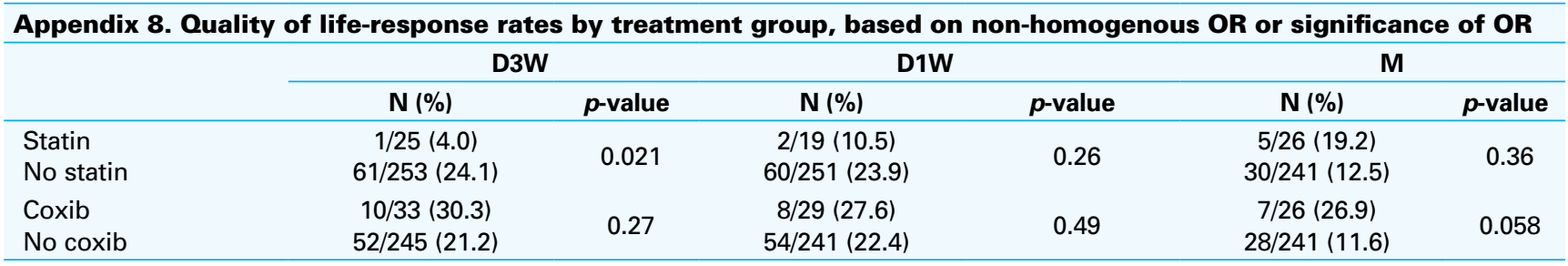

OR: odds ratio; D3W: docetaxel 3 weekly; D1W: docetaxel weekly; M: mitoxantrone.

\begin{tabular}{|c|c|c|c|c|}
\hline \multicolumn{5}{|c|}{$\begin{array}{l}\text { Appendix 9. Median number of cycles delivered and } \\
\text { median weeks on chemotherapy, patients on concomitant } \\
\text { medication }\end{array}$} \\
\hline & D3W & D1W & M & $\begin{array}{c}\text { Median } \\
\text { weeks }\end{array}$ \\
\hline Metformin & 6 & 4.5 & 7 & 20.6 \\
\hline ‘Prazole' & 9 & 4 & 6 & 23.1 \\
\hline Glyceryl & 6 & 4 & 5 & 15.9 \\
\hline Digoxin & 3 & 4 & 7 & 16.1 \\
\hline Verapamil & 4 & 4 & 4.5 & 11.1 \\
\hline Statin & 7 & 5 & 5.5 & 18.1 \\
\hline 'Coxib' & 9 & 4.5 & 6 & 23.4 \\
\hline Warfarin & 10 & 5 & 7 & 26.9 \\
\hline ‘Parin' & 6 & 5 & 8 & 21.1 \\
\hline Ascorbic acid & 6 & 5 & 6 & 19.4 \\
\hline Selenium & 5 & 4 & 5 & 18.1 \\
\hline Tocopherol & 6 & 4 & 6 & 18.1 \\
\hline Anti-depressants & 10 & 5 & 6 & 24.1 \\
\hline Epoetin & 10 & 4 & 7 & 24.1 \\
\hline Aspirin & 9 & 4 & 7 & 21.1 \\
\hline
\end{tabular}

D3W: docetaxel 3 weekly; D1W: docetaxel weekly; M: mitoxantrone. 